\title{
SISTEM PERTAHANAN JEPANG DI JAWA \\ Studi Berdasarkan Tinggalan Gua Jepang Di Banyumas, Jawa Tengah ${ }^{1}$
}

\section{JAPANESE DEFENSE SYSTEM IN JAVA \\ A Study Based on Remnants of Japanese Bunkers In Banyumas, Central Java}

Muhammad Chawari

Balai Arkeologi Yogyakarta

\begin{abstract}
Towards mid of $20^{\text {th }}$ century Indonesia was not yet fully freed from suffering, particularly the Japanese occupation. During the period of 3 years, from 1942 to 1945 Japan seized Indonesia. First they landed in is East Kalimantan. From here they occupied the entire archipelago. To defend the territory, the built numerous fortress called bunker. The term often used to refer to Japanese Caves. Japanese bunker and Japanese caves are different. Bunkers were made of a mixture of cement, stone, and sand, while the cave were made by drilling holes in the hills horizontally, the entire Japanese defense system in Banyumas are caves. By observing Japanese caves, particularly in Banyumas, we can learn about the defense system elaborated by the Japanese in Java during their occupation.
\end{abstract}

Keywords : Japan, Defense System, Caves, and Banyumas

\begin{abstract}
ABSTRAK
Menjelang pertengahan abad XX Bangsa Indonesia belum sepenuhnya terbebas dari penderitaan, khususnya yang dinamakan penjajahan. Selama kurun waktu 3 tahun yaitu tahun 1942 hingga 1945 Jepang menguasai Indonesia. Daerah pertama yang ditaklukkan adalah Kalimantan Timur. Dari lokasi ini menyebar hingga ke seluruh Nusantara. Untuk mempertahankan wilayah kekuasaannya, Bangsa Jepang banyak mendirikan benteng pertahanan yang disebut dengan bunker. Istilah bunker sering juga digunakan untuk menyebut Gua Jepang. Sebetulnya antara bunker dengan gua Jepang berbeda. Bunker merupakan peninggalan Jepang yang dibuat dengan cor yang merupakan campuran antara semen, pasir, dan batu (kerikil), sedangkan gua Jepang dibuat dengan cara melubangi bukit secara horisontal. Peninggalan Jepang yang ada di Banyumas seluruhnya merupakan Gua Jepang. Secara umum dari studi tentang Gua Jepang (khususnya yang ada di Banyumas) dapat dilihat dan diketahui cara atau sistem yang digunakan Bangsa Jepang dalam mempertahankan wilayah kekuasaannya, khususnya daerah jajahannya.
\end{abstract}

Kata kunci: Jepang, Sistem Pertahanan, Gua, dan Banyumas

Tanggal masuk : 7 Februari 2013

Tanggal diterima : 26 April 2013

\footnotetext{
${ }^{1}$ Karya tulis ilmiah ini dengan beberapa pengurangan dan penambahan pernah disampaikan pada Forum Peneliti di Lingkungan Kemdikbud yang dilaksanakan oleh Badan Penelitian dan Pengembangan Kementerian Pendidikan dan Kebudayaan pada tanggal 2 s.d. 5 November 2012 di Lombok, NTB.
} 


\section{PENDAHULUAN}

Banyumas merupakan salah satu kabupaten yang terdapat di Propinsi Jawa Tengah. Ibu kota Kabupaten Banyumas berada di Purwokerto. Daerah Purwokerto dan sekitarnya banyak menyimpan sisasisa peninggalan Jepang. Terdapat beberapa peninggalan masa Jepang yang berupa gua. Gua Jepang ini salah satunya terdapat di Desa Tambaknegara, Kecamatan Rawalo. Gua Jepang oleh masyarakat setempat dikenal dengan nama "Kodo". Istilah "kodo" berarti parit, sebab pada awalnya gua-gua tersebut dikelilingi oleh parit. Pada awalnya Gua Jepang ini terdiri atas tiga (3) gua yang tersebar di beberapa lokasi di Desa Tambaknegara, Kecamatan Rawalo. Pada jaman pendudukan Jepang gua-gua ini digunakan oleh tentara Jepang sebagai bunker untuk bersembunyi dari serangan pejuang Indonesia. Dewasa ini dua (2) gua sudah tertutup oleh longsoran tanah, sementara satu (1) gua dalam kondisi tidak terawat. Sebagai salah satu saksi sejarah sudah selayaknya jika gua-gua tersebut dan kawasan sekitarnya dikelola dengan serius untuk mempertahankan jejak sejarahnya (Anonim 2009, 1-2). Selain di Kecamatan Rawalo, gua Jepang juga ditemukan di Kecamatan Kebasen (Chawari 2012, 16-22).

Terkait dengan keberadaan sisa-sisa kejayaan Jepang di Jawa tersebut (khususnya yang ada di Kecamatan Rawalo), Pemerintah Daerah Kabupaten Banyumas melalui Dinas Kebudayaan dan Pariwisata pada tahun 2009 telah menyusun Buku Rencana Masterplan Goa Jepang Walidadi, Tambaknegara, Kecamatan Rawalo. Studi tersebut memuat rencana pengembangan yang memakan waktu selama 5 tahun dan terbagi atas Rencana Pelaksanaan Pembangunan Tahun 1 hingga Tahun 5 (Anonim 2009, 61).

Tulisan ini pada mulanya diilhami oleh adanya peristiwa sejarah yaitu Perang Pasifik. Perang ini dipicu oleh ambisi Jepang dalam usahanya untuk membangun suatu imperium di Asia. Hal ini berhubungan dengan ambisi Jepang untuk memiliki bahan industri dari negara-negara selatan termasuk Indonesia. Penyerangan Jepang pertama di Indonesia dilakukan pada 10 Januari 1942 yaitu di Tarakan, Kalimantan Timur, kemudian berturut-turut bergerak ke wilayah Balikpapan, Pontianak, dan Banjarmasin yang diduduki pada tanggal 10 Februari 1942. Setelah Palembang diduduki pada tanggal 16 Februari 1942, barulah Jepang melakukan penyerangan ke Pulau Jawa. Kemenangan-kemenangan Jepang dalam pertempuran memudahkan pasukannya mendarat di Pulau Jawa. Jepang mendaratkan Devisi ke-2 di Jawa Barat, dan Divisi ke-48 di Jawa Tengah. Kekuatan Jepang ini yang khusus dipergunakan untuk merebut Pulau Jawa berada di bawah komando Tentara 16 (Osamu Butai) yang dipimpin oleh Letnan Jenderal Hitozhi Imamura (Kartodirdjo, dkk. 1976, 1-2).

Sebagai sarana peperangan dan untuk mempertahankan diri maupun untuk mengawasi daerah kekuasaannya, Jepang mendirikan tempat-tempat pertahanan maupun perlindungan, seperti halnya Belanda dengan mendirikan bentengbenteng pertahanan di beberapa wilayah di Indonesia sebagai sarana pertahanan terhadap serangan musuh.

Sarana pertahanan Jepang sampai sekarang masih dapat kita lihat antara lain di wilayah Jawa Tengah yaitu di Kabupaten Boyolali. Di wilayah Jawa Timur juga terdapat beberapa bunker maupun guagua peninggalan Jepang sebagai sarana pertahanan, yaitu yang terdapat di tempattempat strategis mulai pantai utara Jawa sampai bagian selatan. Sebuah bunker militer sampai saat ini dapat kita lihat di Bajul Mati, Kabupaten Banyuwangi yang terletak di jalan raya Surabaya Banyuwangi. Selain itu juga ditemukan bunker Jepang di perkebunan dan hutan konservasi Merubetiri, Kabupaten Jember, Propinsi Jawa Timur.

Bahkan di luar Jawa yaitu di Bukittingi terdapat bunker sepanjang $9 \mathrm{~km}$ di bawah pusat kota. Namun dari sekian banyak tinggalan-tinggalan sisa pertahanan Jepang, belum pernah dilakukan penelitian baik mengenai persebarannya maupun tipologinya, khususnya yang terdapat di P. Jawa. 
Penelitian tahap pertama dilaksanakan di Kabupaten Sleman dan Kabupaten Bantul, Propinsi Daerah Istimewa Yogyakarta, serta Kabupaten Purworejo Propinsi Jawa Tengah pada tahun 2010 yang lalu. Temuan sebaran bunker dan Gua Jepang pada masa perang dunia ke-2 di Kabupaten Sleman, tepatnya di kawasan wisata Kaliurang berjumlah 19 gua. Bangunan Gua Jepang ini terdapat di lereng kaki Gunung Merapi sebelah barat atau tepatnya di atas bekas pemandian telaga Nirmala. Gua-gua Jepang ini dibuat pada dinding lereng bukit dengan melubangi lereng secara horisontal. Letak gua-gua tersebut, karena pembuatannya terletak pada satu jalur jalan setapak. Masing-masing gua jumlah pintunya tidak sama, bervariasi antara satu hingga tiga pintu, namun kebanyakan hanya memiliki satu pintu.

Begitu pula kedalaman lorong gua sangat bervariasi. Selain di Kaliurang, Gua Jepang ditemukan pula di Dusun Sentonorejo, Desa Jokotirto, Kecamatan Berbah, Kabupaten Sleman. Di wilayah ini terdapat bangunan Gua Jepang. Bangunan gua dibuat pada dinding batu padas dengan lebar pintu gua bervariasi begitu juga kedalamannya.

Sementara itu sebaran temuan karya bangsa Jepang di Kabupaten Bantul, secara administratif berada di Dusun Payahan, Desa Seloharjo, Kecamatan Pundong. Di wilayah ini tinggalan masa Jepang berupa bunker. Objek ini berada di atas perbukitan di tepi Pantai Parangtritis. Bangunan bunker Jepang di daerah ini berjumlah 18 . Seluruh tinggalan bangunan bunker Jepang yang ada di lokasi ini dibuat dari cor semen.

Berikutnya bunker Jepang di Kabupaten Purworejo yang sementara ini didata berjumlah 10. Menurut keterangan juru pelihara yaitu Bapak Tarman (40 tahun) sebenarnya secara keseluruhan bunker yang ada berjumlah 40. Namun baru 10 yang berhasil dibuka. Sisanya masih tertutup semak-semak belukar. Dari lokasi ditemukannya bunker Jepang ini dapat dilihat jalur jalan raya yang menghubungkan Yogyakarta dengan daerah-daerah di sebelah Barat. Keseluruhan objek tinggalan Jepang yang ditemukan dibangun dengan menggunakan cor semen (Widodo 2010, 3).

Selanjutnya berdasarkan uraian tersebut di atas, terdapat beberapa permasalahan yang dapat dirinci sebagai berikut:

a. Bagaimana kondisi dan keadaan sarana pertahanan Jepang pada masa Perang Dunia ke-2 yang ada di wilayah Jawa Tengah (khususnya Kabupaten Banyumas).

b. Bagaimana tipologi sarana pertahanan Jepang pada masa Perang Dunia II.

c. Bagaimana sistem pertahanan Jepang yang ada di Indonesia, khususnya di Jawa.

Berkaitan dengan permasalahan di atas, maka tujuan penelitian ini adalah:

a. Mengidentifikasi tipologi sarana pertahanan.

b. Mengetahui sistem pertahanan Jepang di Jawa.

Berangkat dari tujuan yang telah dicanangkan, maka jenis penelitian yang akan dilakukan ini adalah deskriptif eksplanatif. Dalam metode ini akan dilakukan analisis berbagai peninggalan sarana pertahanan Jepang secara deskriptif. Berdasarkan pada metode penelitian yang dipilih tersebut, maka beberapa tahapan yang akan dilakukan dalam penelitian ini antara lain adalah:

a. Pengumpulan data dilakukan melalui studi literatur hasil penelitian terdahulu dan informasi masyarakat lokal yang kemudian ditindaklanjuti dengan kegiatan survei atau observasi lapangan.

b. Analisis data yang dilakukan mencakup analisis data arkeologis, yaitu meliputi analisis sarana pertahanan Jepang. Analisis data arkeologi dengan penekanan pada aspek fungsional bertujuan untuk merekonstruksi sarana pertahanan Jepang pada masa PD II.

c. Sintesis dilakukan dengan menyimpulkan hasil penelitian yang bertujuan untuk merekonstruksi sarana pertahanan Jepang. Implikasi teoritis dari penelitian ini adalah pemahaman mengenai sarana pertahanan Jepang pada masa PD II. 
Dalam rangka untuk memberikan arah pemikiran dalam karya tulis ini maka akan diuraikan secara ringkas tentang kerangka pikir penulis sebagai landasannya. Perang Pasifik lama kelamaan semakin melemahkan sepak terjang tentara Jepang. Kondisi yang demikian ini memaksa pemerintah Jepang untuk mengambil langkah yang taktis. Langkah tersebut adalah dengan cara menerapkan dua kebijakan yang saling bertolak belakang. Kedua cara tersebut dapat dipilah yaitu fisik dan non-fisik. Kegiatan non-fisik dilakukan dengan cara menarik hati rakyat Indonesia. Secara nyata upaya ini dilakukan dengan cara memberikan kesempatan kepada putraputra Indonesia untuk ambil bagian dalam pengelolaan pemerintahan negara, yaitu meliputi badan-badan pertimbangan di daerah maupun di pusat. Juga dalam jabatan-jabatan tinggi serta penasehat di bidang kemiliteran (Notosusanto 1976, 12).

Sementara itu kegiatan fisik berupa pembangunan sarana pertahanan. Dalam mempertahankan wilayah kekuasaannya Jepang telah membangun berberapa sarana pertahanan sesuai dengan situasi dan kondisi setiap daerah. Berdasarkan latar belakang dan tujuan penelitian maka pada saat penelitian akan dilakukan pengumpulan data terhadap tinggalantinggalan sarana pertahanan Jepang pada masa PD II di daerah penelitian dengan melalui survei lapangan juga didukung dengan mencari bahan-bahan pustaka yang meliputi sumber-sumber tertulis.

\section{PERSEBARAN DAN KEBERADAAN GUA JEPANG}

Tinggalan masa Jepang yang ada di Kabupaten Banyumas berada di dua kecamatan, yaitu Kecamatan Rawalo dan Kecamatan Kebasen. Pemberian nama dan identifikasi terhadap masing-masing gua disesuaikan dengan nama kecamatan, misalnya gua Jepang RWL-02 (gua Jepang nomor 2 di Kec. Rawalo), dan KBS-04 (gua Jepang nomor 4 di Kec. Kebasen). Uraian hasil survei akan diurutkan sesuai dengan lokasi yang pertamakali dikunjungi yaitu Kecamatan Rawalo disusul Kecamatan Kebasen.

\section{Kecamatan Rawalo}

Di Dusun Kalibacin, Desa Tambaknegara, Kecamatan Rawalo terdapat empat gua Jepang. Seluruh gua yang ditemukan berada pada beberapa lereng bukit. Lahan tempat keberadaan keempat gua merupakan perbukitan hutan pinus milik Perhutani Kabupaten Banyumas, khususnya KPH Banyumas Timur. Keempat gua tersebut adalah sebagai berikut:

\section{Gua Jepang RWL-0I}

Secara astronomis gua ini terletak pada S : $07^{\circ} 31^{\prime} 19,8^{\prime \prime}$ dan E : $109^{\circ} 11^{\prime}$ $54,0 "$. Gua menghadap ke arah barat, yaitu

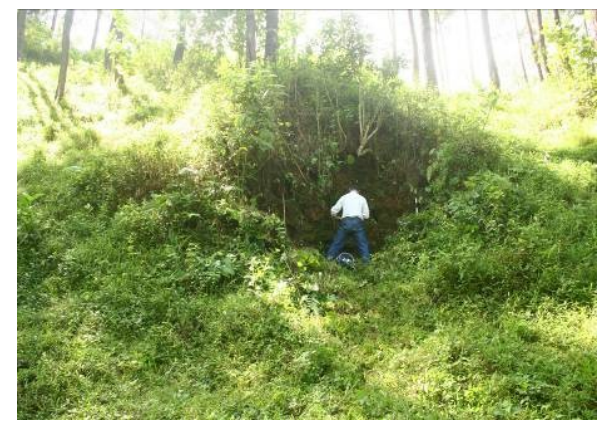

Foto 1. Mulut Gua Jepang RWL-01 yang sebagian telah tertutup tanah

ke arah Sungai Serayu dan Jl. Raya Purwokerto - Bandung. Gua ini denahnya berbentuk seperti huruf i dengan ukuran panjang 25 meter. Untuk memasuki gua terdapat satu pintu yang terletak di barat. Pintu (jalan masuk) sekarang sebagian besar telah tertutup tanah dan hanya sebagian kecil yang terbuka. Jalan masuk (pintu) gua berukuran lebar $215 \mathrm{~cm}$ dan tinggi $150 \mathrm{~cm}$.

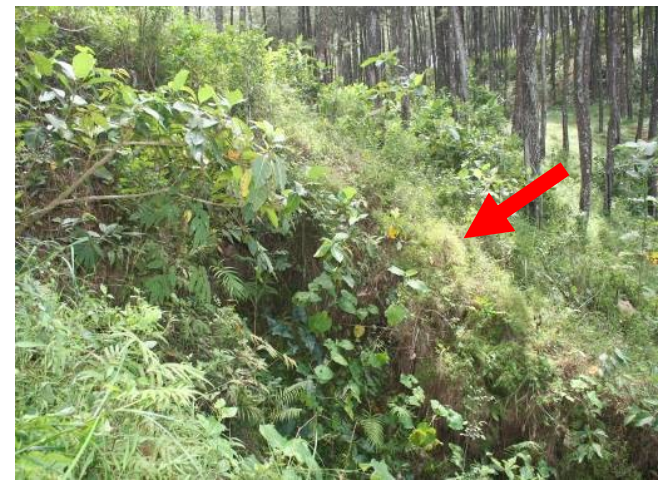

Foto 2. Pintu Gua Jepang RWL-02 yang telah tertutup tanah dan pohon 


\section{Gua Jepang RWL-02}

Secara astronomis objek ini terletak pada $S: 07^{\circ} 31^{\prime} 19,2^{\prime \prime}$ dan E : $109^{\circ} 11^{\prime}$ 55,5". Gua atau "kodo" ini menghadap ke arah timur, yaitu Sungai Serayu dan JI. Raya Purwokerto - Bandung. Gua memiliki dua pintu yang berjarak 20 meter dan sekarang keduanya telah tertutup tanah. Menurut informasi penduduk, kedalaman gua mencapai 25 meter kemudian berbelok ke kanan sepanjang 20 meter dan belok ke kanan lagi sejauh 25 meter hingga mencapai pintu kedua. Dengan demikian gua ini denahnya berbentuk seperti huruf U.

\section{Gua Jepang RWL-03}

Secara astronomis objek ini terletak pada $S: 07^{\circ} 31^{\prime} 13,2^{\prime \prime}$ dan $E$ : $109^{\circ} 11^{\prime}$ 58,1 ". "Kodo" ini menghadap ke arah barat, atau ke arah Jl. Raya Purwokerto Bandung. Untuk masuk ke dalam gua terdapat satu pintu yang sekarang telah tertutup tanah. Menurut informasi penduduk yang menjadi penunjuk jalan, kedalaman gua mencapai 25 meter.

\section{Gua Jepang RWL-04}

Secara astronomis objek ini terletak pada $S: 07^{\circ} 31^{\prime} 11,2^{\prime \prime}$ dan $E$ : $109^{\circ} 11^{\prime}$ 53,1". Gua ini menghadap ke arah tenggara, atau Jl. Raya Purwokerto Bandung. Untuk masuk ke dalam gua terdapat satu pintu dan sekarang telah tertutup seluruhnya oleh tanah.

\section{Kecamatan Kebasen}

Di Dusun Losari dan Dusun Beji, Desa Gambarsari, Kecamatan Kebasen ditemukan gua Jepang yang seluruhnya berjumlah delapan. Seluruh gua Jepang

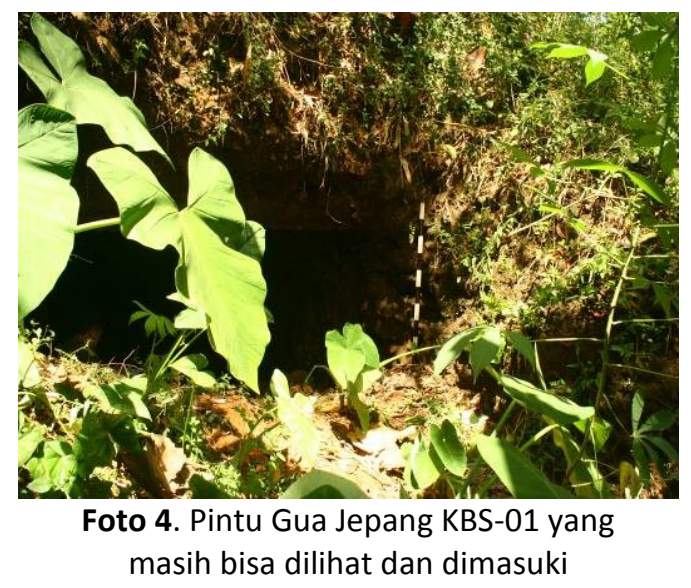

Berkala Arkeologi Vol.33 Edisi i No.1/Mei 2013 berada pada lereng sebuah bukit atau gunung yaitu Gunung Brojol. Lahan tempat keberadaan kedelapan gua ini merupakan perbukitan hutan pinus, sengon, dan jati milik Perhutani Kabupaten Banyumas, khususnya KPH Banyumas Timur dan sebagian ada yang terletak pada lahan milik waga desa setempat. Kedelapan gua tersebut adalah sebagai berikut:

\section{Gua Jepang KBS-01}

Secara astronomis objek ini terletak pada S : $07^{\circ} 31^{\prime} 30,6^{\prime \prime}$ dan E: $109^{\circ} 12 ' 21,4^{\prime \prime}$. Gua Jepang ini menghadap ke arah barat laut, yaitu ke arah Jl. Raya Purwokerto Bandung dan jalur kereta api antara Purwokerto - Kroya. Gua Jepang ini memiliki satu pintu dengan ukuran lebar $265 \mathrm{~cm}$ dan tinggi $185 \mathrm{~cm}$, sekarang sebagian tertutup tanah. Gua ini denahnya berbentuk seperti huruf i dengan ukuran panjang 15,6 meter, lebar 2,65 meter, dan tinggi 1,85 meter.

\section{Gua Jepang KBS-02}

Secara astronomis objek ini terletak pada S : $07^{\circ} 31^{\prime} 30,3^{\prime \prime}$ dan E : $109^{\circ} 12^{\prime}$ 22,6". Objek ini menghadap ke arah timur laut yaitu ke Pegunungan Brojol. Gua memiliki satu pintu masuk yang dewasa ini telah tertutup tanah dan menyisakan lubang kecil di bagian atas.

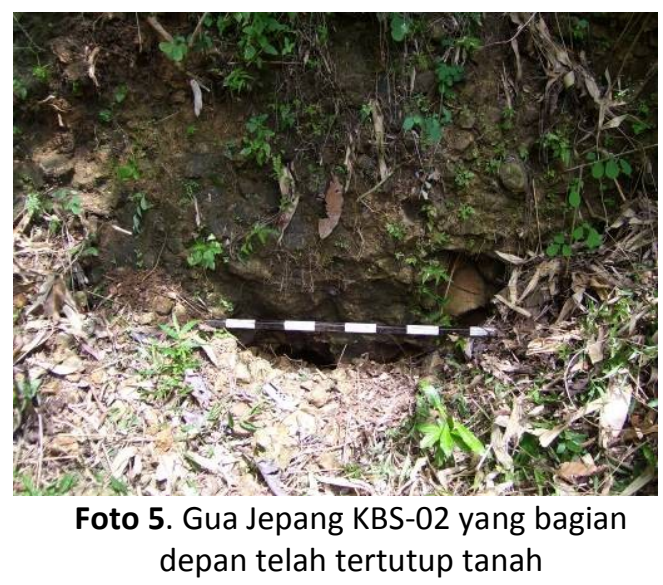

\section{Gua Jepang KBS-03}

Secara astronomis objek ini terletak pada $S: 07^{\circ} 31^{\prime} 31,9^{\prime \prime}$ dan E : $109^{\circ} 12^{\prime}$ 20,5". Objek ini menghadap ke arah barat daya yaitu ke Jl. Raya Purwokerto Kebasen - Sampang, juga jalur kereta api antara Purwokerto - Kroya - Cilacap, dan Sungai Serayu. Gua Jepang ini memiliki 
satu pintu yang sekarang seluruhnya telah tertutup longsoran tanah. Selain itu posisi mulut gua berada pada tebing atau lereng Pegunungan Brojol yang sangat curam menyebabkan objek ini sangat sulit untuk didatangi.

\section{Gua Jepang KBS-04}

Secara astronomis objek ini terletak pada $S: 07^{\circ} 31^{\prime} 31,1^{\prime \prime}$ dan E : $109^{\circ} 12^{\prime}$ 17,2". Gua Jepang ini menghadap ke arah barat laut yaitu ke Sungai Serayu, JI. Raya Purwokerto - Kebasen - Sampang, dan jalur kereta api antara Purwokerto - Kroya - Cilacap. Gua ini memiliki satu pintu yang berukuran lebar 2,75 meter dan tinggi 1,55 meter, namun separo bagian telah tertutup tanah. Gua ini denahnya berbentuk seperti huruf i dengan ukuran panjang 15 meter. Selain itu posisi mulut gua berada pada tebing atau lereng gunung yang cukup curam menyebabkan objek ini sangat sulit untuk didatangi.

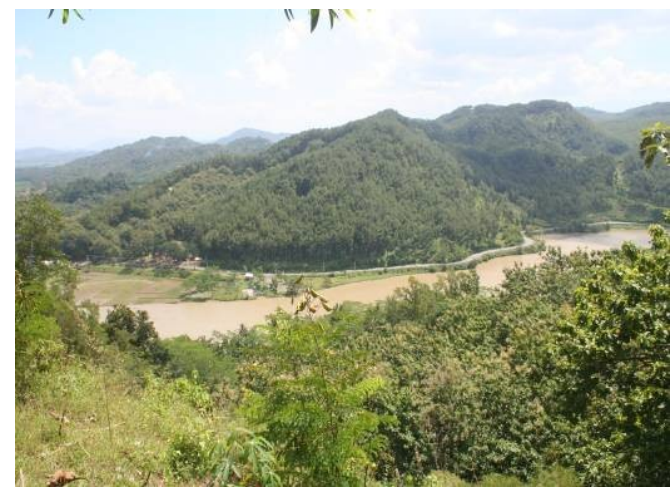

Foto 6.Sasaran Gua Jepang KBS-04 adalah lalu lintas di sekitar Sungai Serayu

\section{Gua Jepang KBS-05}

Secara astronomis objek ini terletak pada $S: 07^{\circ} 31^{\prime} 22,5^{\prime \prime}$ dan E : $109^{\circ} 12^{\prime}$ 24,1". Gua Jepang ini menghadap ke arah barat, yaitu ke arah Sungai Serayu, Jl. Raya Purwokerto - Kebasen - Sampang Cilacap, dan jalur kereta api jurusan antara Purwokerto - Kroya - Yogyakarta. Gua memiliki satu pintu masuk yang seluruhnya telah tertutup longsoran tanah. Selain itu posisi mulut gua berada pada tebing atau lereng Gunung Brojol sebelah barat laut dan letaknya sangat curam menyebabkan objek ini sangat sulit untuk didatangi.

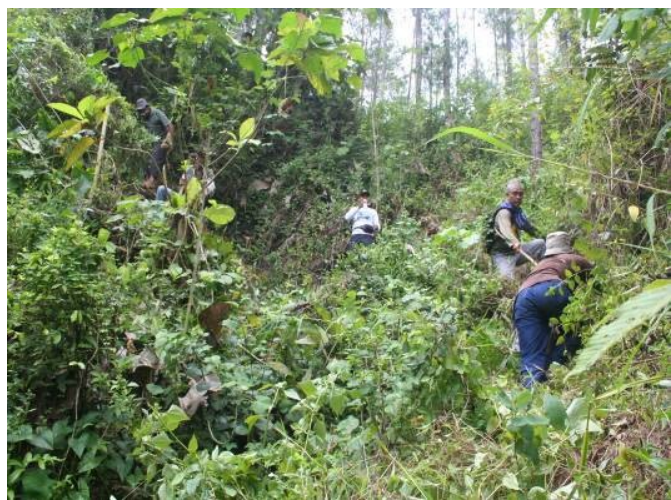

Foto 7. Untuk sampai ke Gua Jepang KBS-05 harus melalui medan yang cukup berat

\section{Gua Jepang KBS-06}

Secara astronomis gua ini terletak pada S : $07^{\circ} 31^{\prime} 23,9^{\prime \prime}$ dan E : $109^{\circ} 1^{\prime}$ 34,6". Objek ini menghadap ke arah utara, yaitu ke Sungai Serayu, Jl. Raya Purwokerto - Kebasen - Sampang Cilacap, jalur kereta api jurusan Purwokerto - Kroya - Yogyakarta, dan Jl. Raya Purwokerto - Bandung. Gua memiliki satu pintu yang sekarang telah tertutup longsoran tanah.

\section{Gua Jepang KBS-07}

Secara astronomis gua Jepang ini terletak pada $\mathrm{S}: 07^{\circ} 31^{\prime} 39,5^{\prime \prime}$ dan $\mathrm{E}:{ }^{\circ}{ }^{\circ}$ 12' 41,8". Objek ini menghadap ke arah timur, yaitu hutan di sekitar bukit dan Sungai Mangir, yaitu sungai kecil di kawasan ini. Gua memiliki satu pintu dan seluruhnya telah tertutup longsoran tanah. Menurut informasi penduduk, gua Jepang ini memiliki kedalaman mencapai 15 meter dan denahnya berbentuk seperti huruf $i$.

\section{Gua Jepang KBS-08}

Secara astronomis gua ini terletak pada $S: 07^{\circ} 31^{\prime} 40,0^{\prime \prime}$ dan E : $109^{\circ} 12^{\prime}$ $43,2 "$. Tinggalan Jepang ini menghadap ke arah utara yaitu langsung mengarah ke hutan di sekitar bukit dan Sungai Mangir yaitu sungai kecil yang ada di kawasan ini. Gua memiliki satu pintu, sekarang telah tertutup tanah. Menurut informasi penduduk, gua Jepang ini memiliki kedalaman mencapai sekitar 15 meter dan denahnya berbentuk seperti huruf i. 


\section{SISTEM PERTAHANAN JEPANG PADA MASA PERANG DUNIA II}

\section{Klasifikasi Sarana Pertahanan Jepang}

Data tinggalan masa pendudukan Jepang yang diperoleh di lokasi penelitian yaitu Kabupaten Banyumas semuanya berjumlah 12 objek. Ke-12 objek tersebut semuanya dimasukkan ke dalam klasifikasi gua Jepang. Pengklasifikasian ini didasarkan atas dua hal, yaitu kajian berdasarkan bentuk dan kajian berdasarkan teknologi. Berdasarkan bentuknya, seluruh objek yang ditemukan di Kabupaten Banyumas memenuhi syarat sebagai gua. Menurut Poerwadarminta $(1976,329)$ gua adalah lubang besar pada kaki gunung. Secara umum yang dimaksud dengan gua dapat dibagi menjadi dua berdasarkan terjadinya, yaitu gua alam dan gua buatan. Gua alam adalah suatu rongga di bawah tanah yang terbentuk secara alami (Anonim, 1989: 239). Dengan divinisi seperti itu sudah selayaknya jika objekobjek tersebut disebut dengan gua, yaitu gua buatan. Gua buatan yang dimaksud dalam hal ini adalah gua buatan manusia sebagai hasil "rekayasa" bangsa Jepang menjelang pertengahan abad XX (1942 1945). Secara teknis objek-objek sebanyak 12 gua tersebut dibuat dengan cara melubangi dinding bukit secara horisontal untuk mendapatkan ruang yang cukup terlindung dari pengaruh luar.

\section{Model atau Tipe Sarana Pertahanan Jepang \\ Objek berupa gua Jepang yang} ditemukan di Kabupaten Banyumas semuanya berjumlah 12 . Dari ke-12 objek tersebut terdapat beberapa bentuk sesuai dengan denah bangunannya. Berdasarkan kondisi masing-masing gua, dari ke-12 objek tersebut yang telah diketahui dengan jelas denah bangunannya hanya 3 gua, yaitu gua Jepang RWL-01 (Kecamatan Rawalo) denahnya berbentuk seperti huruf i, Gua Jepang KBS-01 dan KBS-04 (Kecamatan Kebasen) masing-masing denahnya juga berbentuk seperti huruf i. Sementara yang lainnya bentuk denahnya belum diketahui secara pasti. Namun demikian melihat ciri-ciri fisiknya dapat diperkirakan berdasarkan perbandingan dengan gua lain (baik yang ditemukan dalam penelitian tahun 2012 maupun penelitian-penelitian lain sebelumnya).

Berdasarkan penelitian yang sama yang dilakukan pada tahun 2011 di Kabupaten Cilacap dan Kabupaten Kebumen serta temuan gua Jepang RWL01, KBS-01, dan KBS-04 pada penelitian tahun 2012 diketahui bahwa gua yang memiliki satu pintu rata-rata denah bangunannya menyerupai huruf i. Gua yang memiliki dua pintu dimungkinkan denah bangunannya menyerupai huruf $u$. Dengan perbandingan seperti itu, maka gua Jepang RWL-02 yang memiliki dua pintu denah bangunannya diperkirakan bentuknya seperti huruf $u$. Sedangkan gua Jepang RWL-03, RWL-04, KBS-02, KBS03, KBS-05, KBS-06, KBS-07, dan KBS-08 diperkirakan denah bangunannya berbentuk seperti huruf i. Dengan demikian dapat dilihat rinciannya melalui tabel sebagai berikut:

Tabel 1. Bentuk Gua Jepang di Kecamatan Rawalo dan Kebasen

\begin{tabular}{|c|c|c|}
\hline No. & Nama Objek & Model / Bentuk \\
\hline 1. & Gua Jepang RWL-01 & Seperti huruf i \\
\hline 2. & Gua Jepang RWL-02 & Seperti huruf u \\
\hline 3. & Gua Jepang RWL-03 & Seperti huruf i \\
\hline 4. & Gua Jepang RWL-04 & Seperti huruf i \\
\hline 5. & Gua Jepang KBS-01 & Seperti huruf i \\
\hline 6. & Gua Jepang KBS-02 & Seperti huruf i \\
\hline 7. & Gua Jepang KBS-03 & Seperti huruf i \\
\hline 8. & Gua Jepang KBS-04 & Seperti huruf i \\
\hline 9. & Gua Jepang KBS-05 & Seperti huruf i \\
\hline 10. & Gua Jepang KBS-06 & Seperti huruf i \\
\hline 11. & Gua Jepang KBS-07 & Seperti huruf i \\
\hline 12. & Gua Jepang KBS-08 & Seperti huruf i \\
\hline
\end{tabular}


Tabel 2. Persentase Gua Jepang berdasarkan bentuk

\begin{tabular}{|c|l|c|c|}
\hline No. & Model Bentuk & Jumlah & \% \\
\hline 1. & Seperti huruf $\mathrm{u}$ & 1 & 8,33 \\
\hline 2. & Seperti huruf $\mathrm{i}$ & 11 & 91,67 \\
\hline & & $\mathbf{1 2}$ objek & $\mathbf{1 0 0} \%$ \\
\hline
\end{tabular}

\section{Aksesibilitas Antar Sarana Pertahanan Jepang}

Melihat letak seluruh gua Jepang seperti yang telah diuraikan pada bagian deskripsi objek, gua-gua tersebut sekarang letaknya sangat sulit dijangkau. Keadaan yang demikian jika dibandingkan dengan situasi yang terjadi pada saat dan sekitar pembangunan gua tersebut akan menjadi sulit dibayangkan betapa medannya sangat berat. Apalagi jika melihat satu persatu keletakan gua pada saat masih difungsikan, menjadi satu kendala untuk dapat mendekatinya. Dengan keadaan yang demikian ini dapat dibayangan betapa terpencil dan terlindungnya gua-gua Jepang tersebut pada masa gunanya.

Dalam rangka untuk mengatasi medan dan kondisi yang demikian ini diperlukan suatu cara untuk mendekatkan beberapa gua Jepang agar mudah dijangkau oleh para pengguna gua tersebut. Salah satu cara yang diterapkan adalah dengan membuat jalan "khusus". Jalan khusus atau jalan rahasia atau jalan tembus antar gua Jepang sekarang ini di beberapa objek masih dapat dilihat dan dilacak keberadaannya, meskipun sebagian besar telah tertutup semak-semak belukar. Namun demikian keberadaan jalan ini masih terlihat jelas. Keberadaan jalan yang merupakan akses dari dan ke antar gua Jepang ini diketahui sejak penelitian tahap I yang dilakukan pada tahun 2010 dan tahap II tahun 2011. Pada penelitian tahap I yang antara lain dilakukan di Kabupaten Bantul, tepatnya di pegunungan sebelah utara Parangtritis. Di lokasi ini terdapat tinggalan kolonial Jepang yang berupa bunker. Salah satu bunker dilengkapi dengan jalan rahasia. Jalan ini dibuat di depan "mulut" bangker dan berupa jalan sempit yang di kanan-kirinya diberi semacam tanggul setinggi sekitar 1 meter. Tanggul ini dibuat dengan cara menyusun batu-batu kapur menjadi semacam pagar jalan. Cara yang kedua dilakukan dengan memecah gundukan (bukit kecil) dan di bagian tengah dibuat semacam jalan.

Sementara pada penelitian tahap II yang antara lain dilakukan di Kabupaten Cilacap, tepatnya di Pulau Nusakambangan. Di pulau ini pada salah satu bunker dilengkapi dengan jalan tembus antar bunker. Bunker yang ada di Pulau Nusakambangan ini juga dilengkapi dengan jalan tembus yang menghubungkan antar bunker. Namun jalan ini agak berbeda dengan yang ada di Kabupaten Bantul. Jalan "rahasia" yang ada di Pulau Nusakambangan bentuk dan teknik pembuatannya lebih sederhana. Dikatakan sederhana karena bentuknya "hanya" seperti parit biasa. Sementara teknik pembuatannya diperkirakan memakai alat (semacam cangkul) yang secara lurus tanah digali tidak lebih dalam dari $50 \mathrm{~cm}$.

Selanjutnya pada penelitian tahap III yang dilakukan di Kabupaten Banyumas, tepatnya di Kecamatan Rawalo. Di kecamatan ini terdapat tinggalan penjajah Jepang berupa gua yang berjumlah 4 . Salah satu dari keempat gua tersebut, yaitu gua Jepang RWL-02 yang denah bangunannya berbentuk seperti huruf $u$. Di depan pintu masuk pertama gua ini terdapat semacam jalan setapak. Jalan ini oleh masyarakat setempat sering disebut dengan istilah parit atau "kodo". Sedangkan di depan pintu kedua gua RWL-02 terdapat jalan yang cukup lebar. Selain lebar, di kanan kiri jalan ini terdapat semacam talud yang tinggi. Dengan demikian jika ada seseorang 
yang melewati jalan ini tidak mungkin terlihat dari sisi yang lain.

\section{Sasaran Pengamatan Sarana Pertahanan Jepang}

Sasaran serangan yang dimaksud dalam tulisan ini adalah pembuatan atau pendirian gua Jepang yang "mulutnya" diarahkan ke sesuatu yang ada di depannya. Arah gua Jepang ini sangat tergantung dari keberadaan pintu masuk. Dengan melihat letak pintu masuk akan dapat diketahui arah serangan orangorang Jepang terhadap keberadaan lawannya.

Tabel 3. Sasaran pengamatan Gua Jepang

\begin{tabular}{|c|l|c|}
\hline No. & \multicolumn{1}{|c|}{ Nama Objek } & Sasaran Pengamatan \\
\hline 1. & Gua Jepang RWL-01 & S. Serayu dan JI. Raya Purwokerto - Bandung \\
\hline 2. & Gua Jepang RWL-02 & S. Serayu dan Jl. Raya Purwokerto - Bandung \\
\hline 3. & Gua Jepang RWL-03 & Jl. Raya Purwokerto - Bandung \\
\hline 4. & Gua Jepang RWL-04 & Jl. Raya Purwokerto - Bandung \\
\hline 5. & Gua Jepang KBS-01 & $\begin{array}{c}\text { Jl. Raya Purwokerto - Bandung dan jalur KA } \\
\text { Purwokerto - Kroya }\end{array}$ \\
\hline 6. & Gua Jepang KBS-02 & $\begin{array}{c}\text { Pegunungan Brojol, salah satu bukit di Pegunungan } \\
\text { Serayu }\end{array}$ \\
\hline 7. & Gua Jepang KBS-03 & $\begin{array}{c}\text { S. Serayu, Jl. Raya Purwokerto - Sampang, dan jalur } \\
\text { KA Purwokerto - Cilacap }\end{array}$ \\
\hline 8. & Gua Jepang KBS-04 & $\begin{array}{c}\text { S. Serayu, Jl. Raya Purwokerto - Sampang, dan jalur } \\
\text { KA Purwokerto - Cilacap }\end{array}$ \\
\hline 9. & Gua Jepang KBS-05 & $\begin{array}{c}\text { S. Serayu, Jl. Raya Purwokerto - Cilacap, dan jalur } \\
\text { KA Purwokerto - Yogyakarta }\end{array}$ \\
\hline 10. & Gua Jepang KBS-06 & $\begin{array}{c}\text { S. Serayu, Jl. Raya Purwokerto - Cilacap, Jalur KA } \\
\text { Purwokerto - Yogyakarta, dan Jl. Raya Purwokerto - } \\
\text { Bandung }\end{array}$ \\
\hline 11. & Gua Jepang KBS-07 & $\begin{array}{c}\text { Perbukitan di sekitar Pegunungan Brojol dan S. } \\
\text { Mangir }\end{array}$ \\
\hline 12. & Gua Jepang KBS-08 & $\begin{array}{c}\text { Perbukitan di sekitar Pegunungan Brojol dan S. } \\
\text { Mangir }\end{array}$ \\
\hline
\end{tabular}

Dari 12 gua tersebut secara garis besar arah sasaran gua Jepang terbagi menjadi 2 kelompok, yaitu:

Tabel 4. Klasifikasi sasaran pengamatan Gua Jepang

\begin{tabular}{|c|c|c|c|}
\hline No. & Sasaran Pengamatan & Jumlah & Nama Objek \\
\hline 1. & $\begin{array}{l}\text { Lereng perbukitan dan kawasan } \\
\text { sekitar objek }\end{array}$ & 3 gua & $\begin{array}{l}\text { Gua Jepang KBS-02, KBS- } \\
07 \text {, dan KBS-08 }\end{array}$ \\
\hline 2. & $\begin{array}{lrr}\text { S. Serayu, Jl. } & \text { Raya Purwokerto - } \\
\text { Cilacap, Jalur KA Purwokerto - } \\
\text { Yogyakarta, dan Jl. Raya } \\
\text { Purwokerto-Bandung } \\
\end{array}$ & 9 gua & $\begin{array}{l}\text { Gua Jepang RWL-01, RWL- } \\
02 \text {, RWL-03, RWL-04, KBS- } \\
01 \text { KBS-03, KBS-04, KBS- } \\
\text { 05, dan KBS-06 }\end{array}$ \\
\hline & JUMLAH & 12 gua & \\
\hline
\end{tabular}

Tabel 5. Persentase Gua Jepang berdasarkan sasaran pengamatan

\begin{tabular}{|c|c|c|c|}
\hline No. & Arah Sasaran & Jumlah & \% \\
\hline 1. & Lereng perbukitan & 3 & 25 \\
\hline 2. & Jalan darat dan sungai & 9 & 75 \\
\hline & & $\mathbf{1 2}$ objek & $\mathbf{1 0 0} \%$ \\
\hline
\end{tabular}

Dengan melihat tabel tersebut dapat diketahui bahwa sasaran utama orang-orang Jepang dalam membuat gua Jepang adalah jalan atau akses yang 
menghubungan antara kawasan atau antar kota. Jl. Raya Purwokerto Bandung dan Jl. Raya Purwokerto Kebasen - Sampang - Kroya - Cilacap (khususnya jalan yang menghubungkan antara Purwokerto - Cilacap) dinilai yang utama dan paling penting. Hal ini terlihat dari peta kedatangan pengaruh asing ke Jawa salah satunya melalui Pelabuhan Cilacap. Cilacap sebagai kota pelabuhan dan Purwokerto mewakili kota pedalaman.

Selain jalan darat masih ada dua (2) jalur perhubungan, yaitu jalur lalu lintas kereta api dan jalur lalu lintas air melalui Sungai Serayu. Jalur lalu lintas kereta api ke barat menghubungkan dengan daerah pusat kekuasaan yaitu Jakarta dan ke timur menghubungkan dengan daerah berada di pantai selatan yaitu di kota Cilacap, sedangkan bagian hulu berada di daerah pedalaman Jawa Tengah, tepatnya di Banjarnegara. Sungai ini panjangnya mencapai $120 \mathrm{~km}$ dan melewati empat (4) kabupaten, yaitu: Cilacap, Banyumas, Purbalingga, dan Banjarnegara. Sungai ini di bagian hulu merupakan gabungan banyak mata air dan sungai kecil di pegunungan Jawa Tengah. Diperkirakan dengan sukses dan berhasil mengamankan jalur tersebut kepentingan Jepang di Jawa akan selalu dapat terjaga.

Kawasan yang menjadi sasaran pengamatan dari gua Jepang seperti tersebut berada pada kawasan dataran rendah yang terletak dan diapit oleh dua lembah atau pegunungan di sebelah

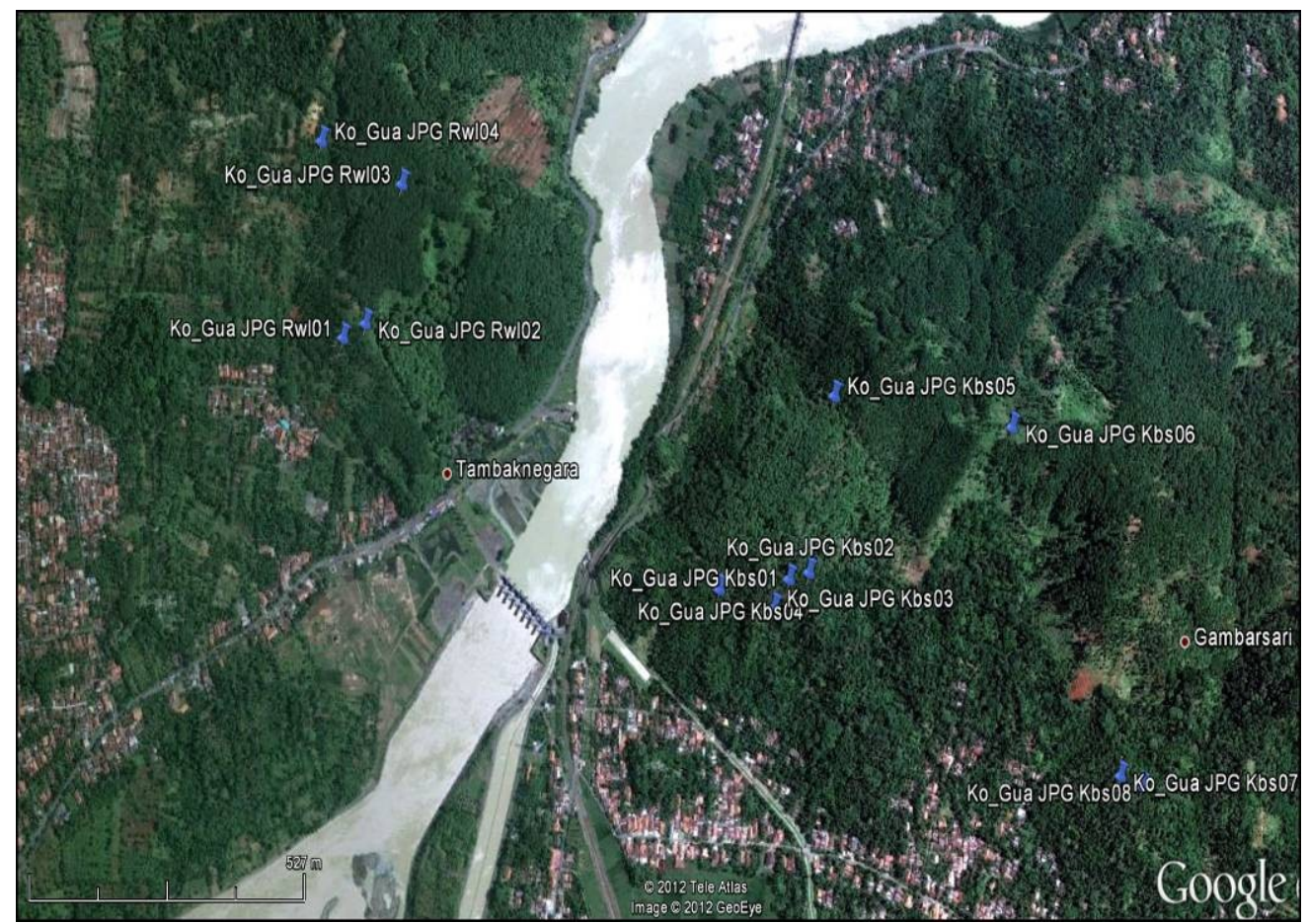

Peta 1. Keletakan Gua Jepang di Kecamatan Rawalo dan Kebasen dengan Sungai Serayu di bagian tengah dan jalur lalu lintas darat serta jalur kereta api

Yogyakarta sebagai bekas ibu kota. Kedua daerah tersebut mempunyai peran yang amat penting di masa lalu. Sementara jalur lalu lintas air melalui Sungai Serayu. Sungai ini bagian hilir kanan dan kiri. Pegunungan di sebelah barat berada di kawasan Kecamatan Rawalo dan pegunungan di sebelah timur berada di kawasan Kecamatan Kebasen. 


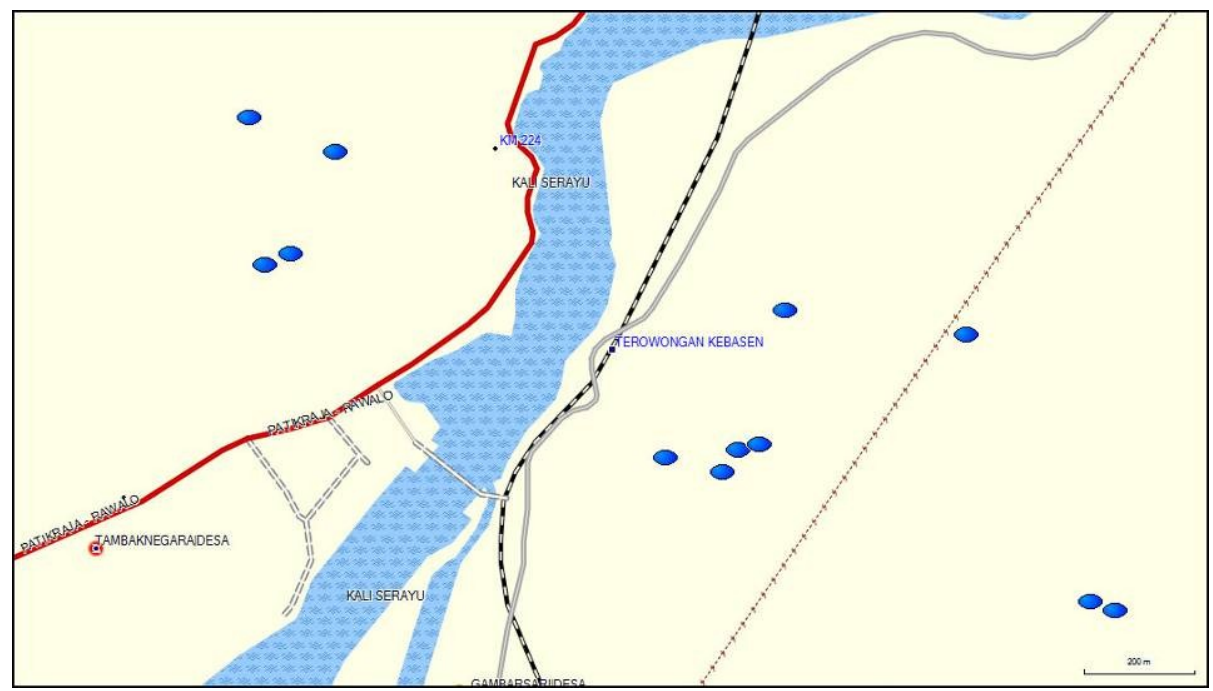

Peta 2. Warna biru adalah Sungai Serayu, warna merah adalah jalan darat antara Purwokerto - Bandung, warna abu-abu jalan darat antara Purwokerto -

Cilacap, dan garis putus-putus adalah jalur kereta api

Demikianlah peta kepentingan Jepang yang berusaha keras untuk dapat menguasai kawasan ini. Orang-orang Jepang berharap apabila dapat menguasai kawasan ini secara otomatis dapat menguasai daerah pantai (pelabuhan) dan pedalaman. Dengan keyakinan seperti ini maka dengan sekuat tenaga orang-orang Jepang mendirikan benteng pertahanan (gua) di kawasan Banyumas.

\section{KESIMPULAN}

Berdasarkan hasil penelitian yang telah dilakukan dan berhubungan dengan berbagai macam bentuk atau tipologi gua Jepang dapat diberikan beberapa kesimpulan sebagai berikut :

a. Terdapat dua (2) tipe atau model gua Jepang, yaitu bentuk seperti huruf $u$, dan seperti huruf i.

b. Terdapat jalan khusus sebagai akses yang menghubungkan antar gua Jepang dalam rangka untuk memperpendek jarak tempuh.

c. Gua Jepang yang demikian ini sebagian besar $(75 \%)$ diarahkan ke jalan (baik darat maupun sungai) sebagai akses dari dan ke Purwokerto. Jalan darat termasuk jalur kereta api. Jalur darat meliputi jalan raya Purwokerto - Bandung, jalan raya Purwokerto - Kebasen Sampang - Cilacap. Sedangkan jalur lalu lintas air melalui Sungai Serayu. Selanjutnya jalur kereta api menghubungkan antara Purwokerto Kroya - Cilacap. Namun ada beberapa (25 \%) gua Jepang yang diarahkan ke bukit di kawasan setempat. Hal ini dapat dimaklumi karena pada saat masuknya tentara Jepang, situasi politik di Kawasan Asia Tenggara (khususnya) masih belum aman karena antara tahun 1942 - 1945 merupakan masa-masa Perang Dunia II. Untuk itu dalam kaitannya dengan penguasaan Jepang terhadap wilayah Indonesia, khususnya daerah Banyumas mendapat prioritas yang sama. Mengingat bahwa setelah Jepang dapat menguasai pantai selatan (khususnya di Cilacap), sasaran berikutnya berada di daerah pedalaman antara lain Banyumas yang beribukota di Purwokerto.

\section{UCAPAN TERIMAKASIH}

Atas terlaksanannya penelitian dan selesainya karya tulis ini tidak lupa disampaikan ucapan terimakasih atas segala bantuan, dukungan, dan kerjasama yang baik, terutama kepada seluruh anggota tim penelitian yang terdiri atas staf peneliti dan administrasi Balai Arkeologi Yogyakarta yaitu: Dra. Novida Abbas, MA; Drs. Sambung Widodo; Drs. 
Masyhudi; Adji Satrio; Z. Dekon Suyanto; dan Bakrun. Juga kepada Drs. Sugeng Riyanto, M.Hum yang telah membantu mengolah peta melalui program mapsource dan google earth. Di samping itu peran serta berbagai pihak, antara lain Kepala Dinas Pemuda, Olah Raga, Kebudayaan dan Pariwisata Kabupaten Banyumas beserta beberapa stafnya.

Ucapan terimakasih ditujukan pula kepada pihak-pihak yang telah membantu suksesnya kegiatan penelitian yaitu Budi
Soma Putra yang beralamat di Desa Tambaknegara, Kec. Rawalo; Dartoyo yang beralamat di Desa Tumiyang, RT.03, RW.01, Kec. Kebasen; Ahmad Rohidin yang beralamat di Desa Tambaknegara, Kecamatan Rawalo; Ruseno yang beralamat di Desa Tumiyang, Kecamatan Kebasen; Kastawi yang beralamat di Desa Gambarsari, Kecamatan Kebasen; dan Nanto yang beralamat di Desa Gambarsari, Kecamatan Kebasen. 
Anonim. 1989. Ensiklopedi Nasional Indonesia Jilid 6. Jakarta: PT. Cipta Adi Pustaka.

Anonim. 2009. Buku Rencana Masterplan Goa Jepang Walidadi, Tambaknegara, Kec. Rawalo. Banyumas: Dinas Kebudayaan dan Pariwisata.

Chawari, Muhammad. 2012. "Sarana Pertahanan Jepang Pada Masa Perang Dunia Ke II (Tahap III)". Laporan Penelitian Arkeologi. Yogyakarta: Balai Arkeologi.

Notosusanto, Nugroho (ed). 1976. Sejarah Nasional Indonesia VI. Jakarta: Departemen Pendidikan dan Kebudayaan.

Poerwadarminta, WJS. 1976. Kamus Umum Bahasa Indonesia. Jakarta: PN. Balai Pustaka.

Widodo, Sambung. 2010. Laporan Ringkas Penelitian Sarana Pertahanan Jepang Pada Masa Perang Dunia Ke II Tahap I. Yogyakarta: EHPA Intern Balai Arkeologi. 
